\title{
MANAJEMEN SUMBER DAYA INSANI (Konsep Dasar Perencanaan dan Analisis Jabatan di Perbankan Syariah)
}

\author{
Nur Rahmawati \\ Universitas Islam Negeri Sunan Ampel (UINSA) Surabaya \\ Email: emmanurrahmawati84@gmail.com
}

\begin{abstract}
In this globalization era, there are many issues in the development of global competition, including unlimited free competition in a particular region or country. This freedom to do business has become the demands and needs of the world community from any angle. So the existence of Human Resource Management (MSDI) is very important for Islamic banking in managing and using Human Resources that function productively, effectively, and efficiently to be able to survive and compete in the global arena.

Human Resources is an infinite gift from Allah SWT, but if human resources are not managed properly, then an institution or company, even the country will be left behind and could be down. An institution, company and country that is unable to progress, the problem is not the quality of the Human Resources, but on the quality of Human Resources Management, how many bad the Human Resources there, if managed properly, it will produce institutions, companies and developed countries. To that end, human resources must be planned carefully, must be analyzed in depth related to positions(jobs) in accordance with the SDI field owned by a sharia banking, so that what is called the right man in one place wasformed.
\end{abstract}

Keywords : Management, Planning, Job Analysis and Banking

\section{PENDAHULUAN}

Di era globalisasi ini banyak sekali isu perkembangan persaingan global, di antaranya adalah persaingan bebas yang tiada batas dalam suatu wilayah atau negara tertentu. Kebebasan untuk berusaha ini telah menjadi tuntutan dan kebutuhan masyarakat dunia dari sudut manapun. Pada akhir abad ke-20, hampir semua negara terjerumus dengan isu ekonomi, teknologi, dan keamanan. Sedangkan pada abad ke-21 menjadi era tanpa batas dengan adanya kebebasan dalam berusaha, kebebasan dalam berpendapat, kebebasan dalam bersaing, sehingga praktis tidak ada lagi batas antar negara-negara. Maka keberadaan Manajemen Sumber Daya Insani (MSDI) ini sangat penting bagi perbankan syariah dalam mengelola, mengatur, mengurus, dan menggunakan Sumber Daya Insani yang berfungsi secara produktif, efektif, dan efisien untuk bisa bertahan dan bersaing di kancah global.

Dalam ajaran Islam segala sesuatu harus dikerjakan dengan rapi, benar dan teratur dan dilakukan oleh orang yang mampu dan ahli dibidangnya. Oleh karena itu karyawan memerlukan pelatihan dan pengembangan agar memiliki kemampuan sesuai bidang pekerjaannya. Melalui Manajemen Sumber Daya Insani bertujuan meningkatkan kemampuan karyawan agar bekerja secara profesional yang sesuai dengan kebutuhan Lembaga Keuangan Syariah. Untuk memperoleh SDI yang diperlukan Perbankan dapat melalui PTN dan dapat melalui pelatihan, pengembangan, sminar, dan lain 
sebagainya. Sebagaimana Allah SWT telah berfirman: ${ }^{1}$

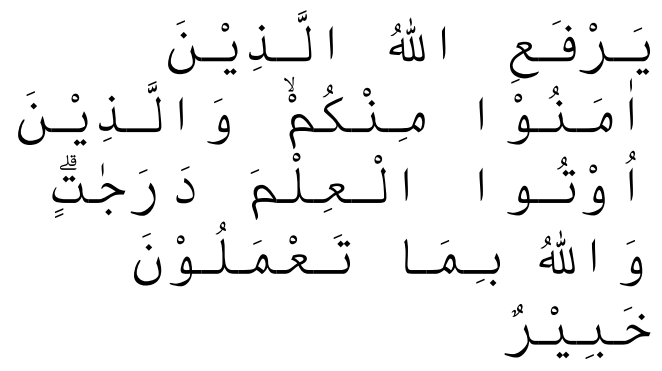

Artinya: Allah akan mengangkat (derajat) orang-orang yang beriman di antaramu dan orang-orang yang diberi ilmu beberapa derajat. Dan Allah Mahateliti apa yang kamu kerjakan.(QS. AlMujadalah (58):11)

Dari deskripsi di atas, maka penulis ingin mengkaji tentang Manajemen Sumber Daya InsaniDalam Konsep Dasar Perencanaan dan Analisis Jabatandi Perbankan Syariah. Dengan rumusan masalah yang terdiri dari: apa definisi dan tujuan manajemen sumber daya insani? Bagaimana manajemen sumber daya insani di perbankan syariah? Dan bagaimana analisis jabatan sumber daya insani di perbankan syariah?

\section{Metode Peneltian}

Penulisan artikel ini menggunakan jenis penelitian kualitatif, pendekatan kualitatif menurut Bogdan dan Taylor adalah metodologi penelitian yang menghasilkan data deskriptif berupa katakata tertulis atau lisan dari orang-orang dan perilaku yang dapat diamati. Pendekatan ini diarahkan pada latar dan individu tersebut secara holistik (utuh). ${ }^{2}$

Pendekatan yang digunakan adalah library research (kajian kepustakaan). Teknik pengumpulan datanya menggunakan dokumentasidan referensi kepustakaan, beberapa data terkait definisi dan tujuan MSDI, manajemen MSDI di

${ }^{1}$ Qur'an Kemenag, Suarah Al-Mujadalah (58) Ayat 11

${ }^{2}$ Lexi J. Moeloeng, Metodologi Penelitian Kualitataif (Bandung: PT Remaja Rosdakarya, 2005), 4. perbankan syariah dan analisis jabatan SDI diperbankah syariah, diambil melalui penelusurankepustakaan. Sedangkan teknik analisis datanya menggunakan teknik analisis deskriptif kualitatif. Analisis deskriptif ini digunakan untuk memecahkan atau menjawab permasalahan yang sedang dihadapi pada situasi sekarang, khususnya terkait manajemen sumber daya insani di perbankan syari'ah, dengan menempuh langkah-langkah pengumpulan, klarifikasi dan analisis data, membuat kesimpulan dan laporan dengan tujuan utama untuk membuat gambaran tentang sesuatu keadaan secara obyektif dalam sesuatu diskripsi situasi. ${ }^{3}$

\section{Definisi dan Tujuan Manajemen Sumber Daya Insani (MSDI)}

Manajemen sumber daya insani (MSDI) merupakan bidang dari manajemen pada umumnya yang meliputi segi perencanaan, pengorganisasian, pelaksanaan dan pengawasan. Proses ini terdapat dalam bidang produksi, pemasaran, keuangan, maupun kepegawaian. Karena sumber daya insani dianggap semakin penting perannya dalam pencapaian tujuan perusahaan, maka berbagai pengalaman dan hasil penelitian dalam bidang Sumber Daya Insani dikumpulkan secara sistematis, maka "manajemen" mempunyai arti sebagai kumpulan pengetahuan tentang bagaimana seharusnya me-manage (mengelola) sumberdaya manusia dengan baik. Sebagaimana dijelaskan dalam firman Allah: ${ }^{4}$

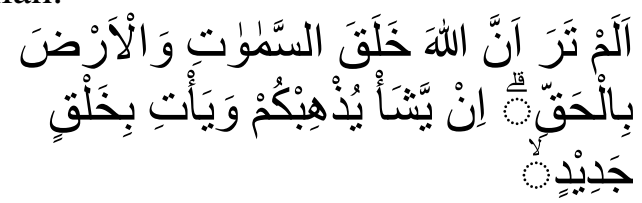

Artinya: Tidakkah kamu memperhatikan, bahwa sesungguhnya Allah telah menciptakan langit dan bumi dengan hak (benar)? Jika Dia menghendaki, niscaya Dia

\footnotetext{
${ }^{3}$ Ali Muhammad, Penelitian Pendidikan Prosedur dan Strategi (Bandung: Angkasa, 1987), 120. ${ }^{4}$ Quran Kemenag, Surah Al Ibrahim (14): 19
} 
membinasakan

kamu

danmendatangkan makhluk yang baru (untuk menggantikan kamu. (QS. AlIbrahim (14): 19)

Pengertian manajemen menurut Fatahullah Juhdi, yaitu sebuah proses mengkoordinasi kegiatan-kegiatan dengan melalui orang lain agar kegiatan-kegiatan yang dimaksud memperoleh hasil (output) yang maksimal, dan dilakukan dengan pendekatan secara efisiensi dan efektif. ${ }^{5}$ Pada umumnya yang sering kita temui dalam pengelolaan perusahan adalah manajemen sumber daya manusia (MSDM) yang berarti suatu sarana untuk memaksimalkan efektifitas organisasi dalam mencapai tujuannya. Di mana Guest berpendapat bahwa suatu kebijakan yang diambil oleh organisasi dalam mengelola SDM diarahkan untuk menyatukan elemen-elemen yang ada dalam organisasional, komitmen pekerja, kelenturan organisasi dalam beroperasi serta pencapaian kualitas hasil kerja secara maksimal. $^{6}$

Menurut Veithzal Rivai Zainal, arti dari Manajemen Sumber Daya Insani (MSDI) sendiri adalah suatu sistem yang terdiri dari banyak aktivitas interdependen (saling terkait satu dengan yang lainnya). ${ }^{7}$

Manajemen perbankan merupakan suatu ilmu yang difokuskan untuk mengatur dan mengelola segala kegiatan operasional di lingkungan perbankan. ${ }^{8}$ Menurut Hasibuan manajemen merupakan ilmu untuk mengatur proses pemanfaatan sumber daya manusia dan sumber-sumber lainnya secara efektif dan efisien untuk

${ }^{5}$ Fathullah Juhdi, Manajemen Sumber Daya Manusia, (Malang: Cita Intrans Selaras, 2018), p. 3.

${ }^{6}$ Priyono dan Marnis, Manajemen Sumber Daya Manusia, (Sidoarjo: ZIFATAMA Publiser, 2008), p. 1-3.

${ }^{7}$ Veithzal Rivai Zainal, Salim Bassalamah, dan Natsir Muhammad, Islamic Human Capital Management Manajemen Sumber Daya Insani, (Jakarta: PT RajaGrafindo Persada, 2014), P. 6

${ }^{8}$ Andrianto dan Anang Firmansyah, Manajemen Bank Syariah Impementasi Teori dan Praktik (T.tt: Qiara Media, 2019), 379. mencapai suatu tujuan tertentu. ${ }^{9}$ Untuk menjaga konsistensi mencapai tujuan manajemen maka setiap usaha harus didahului dengan proses perencanaan yang baik untuk masa depan. ${ }^{10}$

Manajemen sumber daya manusia (Human resource management) adalah proses untuk memperoleh, melatih, menilai, mengompensasi karyawan, dan mengurus relasi tenaga kerja, kesehatan, keselamatan dan hal-hal yang berhubungan dengan keadilan yang bertujuan mewujudkan tujuan-tujuan organisasi dan individu. $^{11}$

Manajemen Sumber Daya Insani di perbankan memiliki persamaan pengertian dengan manajemen sumber daya manusia. ${ }^{12}$ Manajemen sumber daya insani merupakan bidang dari manajemen umum yang berfungsi dalam perencanaan, pengorganisasian, pelaksanaan dan pengendalian sumber daya manusia berdasarkan prinsip islami. ${ }^{13}$ Terdapat beberapa istilah untuk menunjukkan manajemen sumber daya manusia, antara lain: manajemen sumber daya manusia, manajemen sumber daya insani, manajemen personalia, manajemen kepegawaian, manajemen perburuan, manajemen tenaga kerja, administrasi personalia (kepegawaian) dan hubungan industrial. $^{14}$

Dari pengertian di atas penulis ingin menyimpulkan, bahwa Manajemen Sumber Daya Manusia (MSDM) dengan Manajemen Sumber Daya Insani (MSDI) tidaklah jauh berbeda definisinya, namun

\footnotetext{
${ }^{9}$ Melayu S.P. Hasibuan, Manajemen Sumber Daya Manusia Edisi Revisi (Jakarta: Bumi AKsara, 2014), 1.

${ }^{10}$ Zainul Arifin, Dasar-Dasar Bank Syariah (Jakarta: Azkia Publisher, 2009), 114-115.

${ }^{11}$ Saihudin, Manajemen Sumber Daya Manusia (Ponorogo: Uwais Inspirasi Indonesi, 2019), 3.

${ }^{12}$ Jusmaliani, Pengelolaan Sumber Daya Insani (Jakarta: Bumi Aksara, 2011), V.

${ }^{13}$ Silviana Pebruary, dkk, Pencegahan Fraud di Lembaga Keuangan Mikro Syariah (Yogyakarta: Deepublish, 2020), 26.

${ }^{14}$ Mamik, Manajemen Sumber Daya Manusia (Sidoarjo: Zifatama Jawara, 2016), 40.
} 
hanya berbeda dalam kata manusia pada umumnya dengan kata insani yang bermakna insan kamil (dalam bahasa Arab) atau manusia seutuhnya $(a$ whole man concept). Manajemen yang sama-sama memiliki arti pengelolaan pada perusahaan untuk memaksimalkan efektifitas organisasi yang terdiri dari banyak aktivitas terkait satu dengan yang lainnya (interdependen) dalam mencapai tujuannya.

Sumber daya insani di Lembaga Keuangan Syariah (LKS) merupakan suatu usaha untuk meningkatkan kemampuan karyawan agar bekerja secara profesional yang sesuai dengan kebutuhan Lembaga Keuangan Syariah. ${ }^{15}$ Pengelolaan sumber daya insani merupakan pengelolaan sumber daya manusia dengan memperhatikan norma-norma yang berlaku, memberikan rasa keadilan kepada manusia yang terlibat. Perlakuan baik akan memberikan memotivasi karyawan untuk memajukan perusahaan, kemudian akan memunculkan rasa memiliki perusahaan sehingga akan meningkatkan produktivitas kerja karyawan. ${ }^{16}$

Sebagai lembaga knowledge intensive, suatu ketrampilan dan keahlian staf menjadi kunci keberhasilan bank. Selain itu, sumber daya insani bank sangat berpengaruh besar terhadap keberhasilan bank. Dalam sumber daya insani bank dituntut memiliki pengetahuan mengenai ketentuan dan prinsip syariah, memiliki akhlak dan moral islami dalam bekerja meliputi empat ciri pokok, yaitu: (1) shiddiq (benar dan jujur);(2) amanah (dapat dipercaya);(3) tabligh (mengembangkan lingkungan dan bawahan menuju kebaikan); (4) fathonah (kompeten dan profesional). ${ }^{17}$

\footnotetext{
${ }^{15}$ Makhrus, "Peran Perguruan Tinggi dalam Mendorong Pengembangan Sumber Daya Insani pada Lembaga Keuangan Syariah”, Islamadina, Vol .XV, No.2, (November : 2015), 59

${ }^{16}$ Andrianto dan Anang Firmansyah, Manajemen Bank Syariah Impementasi Teori dan Praktik..., 199-200.

${ }^{17}$ Zainul Arifin, Dasar-Dasar Bank Syariah...,120121.
}

Dengan demikian, yang dimaksud dengan Manajemen sumber daya insani adalah suatu perencanaan yang telah dipersiapkan untuk mencapai suatu tujuan organisasi baik yang bersifat materi maupun immaterial melalui potensi-potensi yang dimiliki oleh manusia. Jika dihubungkan dengan manajemen sumber daya insani perbankan syariah, maka MSDI Perbankan Syariah merupakan serangkaian kegiatan pengelolaan sumber daya insani melalui kegiatan perancangan analisis jabatan, perencanaan kerja, rekrutmen dan seleksi, pelatihan dan pengembangan, perencanaan karier, penilaian prestasi kerja sampai dengan pemberian kompensasi yang transparan.

Menurut Shuler et al, MSDI memiliki tiga tujuan utama, yaitu: (1) memperbaiki tingkat produktivitas; (2) memperbaiki kualitas kehidupan pekerja; (3) meyakinkan organisasi telah memenuhi aspek-aspek legal.

Sedangkan kebutuhan sumber daya manusia bank dari waktu ke waktu dapat berubah-ubah, adapun kebutuhan sumber daya manusia paling banyak adalah ketika bank akan membuka cabang baru dan sumber daya manusia akan berkurang apabila bank menutup cabangnya. Secara umum tujuan perencanaan sumber daya manusia pada perusahaan bank meliputi:

1. Pengadaan karyawan, yaitu menyediakan sejumlah tenaga kerja yang akan digunakan pihak perbankan baik untuk jangka pendek maupun jangka panjang

2. Penarikan karyawan, yaitu kegiatan untuk memperoleh sejumlah tenaga kerja melalui sumber tenaga kerja yang tersedia

3. Memperbaiki sumber daya insani yang bertujuan untuk meningkatkan kualitas sumber daya manusia yang ada di perbankan melalui kegiatan pelatihan dan pengembangan atau melalui transfer serta promosi karyawan. ${ }^{18}$

\footnotetext{
${ }^{18}$ Andrianto, dkk., Manajemen Bank (T.tt: Qiara Media, 2019), 195.
} 
Pengelolaan sumber daya Insani yang dilakuka secara baik dan benar bertujuan untuk menghindari hal-hal yang tidak diinginkan, seperti:

Mempekerjakan orang yang tidak tepat pada suatu pekerjaan; (2) Turnover (perputaran karyawan)yang tinggi; (3) Mendapat karyawan yang tidak bekerja secara optimal atau efisien. Pada kenyataannya alasan manusia bekerja adalah untuk mendapatkan gaji, ada juga yang ingin mendapatkan penghargaan, pemanfaatan waktu dan alasan lainnya. Dibalik alasan manusia bekerja, dalam konsep Islam menempatkan manusia sebagai makhluk istimewa yang memiliki potensi sebagai insan kamil.Pada dasarnya tujuan pengelolaan sumber daya insani harus mengakomodasi tujuan hidup manusia dengan menghadirkan Allah swt dalam pengelolaan SDI, sebagaimana dengan konsep kerja yang dinilai ibadah karena dilakukan dengan niat mendekatkan diri kepada Allah SWT. ${ }^{19}$

\section{Manajemen Sumber Daya Insani di Perbankan Syariah}

Dalam sebuah organisasi, manajemen merupakan suatu proses penentuan dan pencapaian tujuan melalui empat fungsi dasar MSDI, yaitu: ${ }^{20}$

1. Perencanaan (planning/ at-takhthiith), merupakan kegiatan untuk memperkirakan keadaan sumber daya manusia agar sesuai dengan kebutuhan organisasi secara efektif dan efisien untuk mewujudkan tujuan organisasi. Dalam perencanaan ini bertujuan untuk menetapkan program-program kepegawaian, meliputi pengorganisasian, pengarahan, pengendalian, pengadaan, pengembangan, kompensasi, integrasi, pemeliharaan, kedisiplinan dan pemberhentian pegawai.

\footnotetext{
${ }^{19}$ Silviana Pebruary, dkk, Pencegahan Fraud di Lembaga Keuangan Mikro Syariah..., 39.

${ }^{20}$ Fahadil Amin Al Hasan dan Muhammad Irfan Maulana, Meningkatkan Kualitas Sumber Daya..., 31.
}

2. Pengorganisasian (organizing/attanziem), yaitu kegiatan untuk mengatur pegawai dengan menetapkan pembagian kerja, hubungan kerja, delegasi wewenang, integrasi dan koordinasi dalam bentuk bagan organisasi.

3. Pengarahan (actuating/at-tansiiq) dan Pengadaan, adalah kegiatan memberikan petunjuk kepada pegawai agar mau bekerja sama dan bekerja secara efektif dan efisien demi tercapainya tujuan organisasi. Pengarahan dilakukan oleh pimpinan yang memberikan pengarahan kepada pegawai agar mengerjakan semua tugasnya dengan baik. Kemudian pengadaan merupakan proses penarikan, seleksi, penempatan, orientasi, dan induksi untuk mendapatkan pegawai yang sesuai dengan kebutuhan organisasi.

4. Pengendalian (controlling/ almuraqabah), merupakan kegiatan mengendalikan pegawai agar menaati peraturan organisasi dan bekerja sesuai dengan rencana. Apabila terdapat penyimpangan akan diadakan tindakan perbaikan atau penyempurnaan. Pengendalian pegawai meliputi, kehadiran, kedisiplinan, perilaku kerjasama dan menjaga situasi lingkungan kerja. ${ }^{21}$

Dalam ajaran Islam segala sesuatu harus dikerjakan dengan rapi, baik dan benar serta tidak boleh dilakukan asalasalan, sebagaimana dijelaskan Rasulullah SAW:

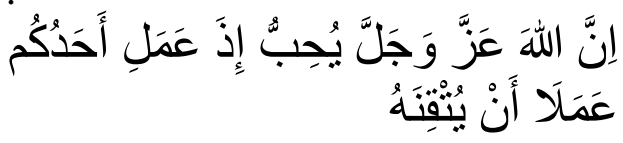

Artinya: "Sesungguhnya Allah sangat mencintai orang yang apabila melakukan sesuatu pekerjaan, dilakukan secara Itqan (tepat, terarah, jelas, dan tuntas)." (HR. Thabrani). ${ }^{22}$

\footnotetext{
${ }^{21}$ Andrianto dan Anang Firmansyah, Manajemen Bank Syariah Impementasi Teori dan Praktik..., 207-208.

المعجم الاوسط باب الألف, من اسمه أحمد, الخز 1 الصفحة 27522
} 
Yang dimaksud dengan itqan adalah segala sesuatu yang memiliki arah yang jelas, landasan yang mantap dan cara mendapatkan yang transparan. Dari pengertian tersebut menunjukkan bahwa dalam Islam menuntut manajemen yang professional dalam suatu lembaga. Kemudian, selain pekerjaan harus dilakukan secara itqan, dalam Islam mengajarkan bahwa suatu pekerjaan harus dilakukan oleh orang yang mampu dan ahli dibidangnya, jika pekerjaan tersebut tidak dilakukan oleh ahlinya maka pekerjaan tersebut akan berantakan dan tidak mencapai tujuan yang dikendaki.

\section{Analisis Jabatan Sumber Daya Insani di Perbankan Syariah}

Sebelum perencanaan SDI dibuat, maka penulis ingin melakukan penjelasan persiapan untuk analisis jabatan terlebih dahulu, kemudian diikuti dengan deskripsi dan spesifikasi jabatan setelah itu baru perencanaan SDI yang sebenarnya dapat dilaksanakan. Sehingga kebutuhan dan permintaan perusahaan terhadap tenaga kerja akan lebih jelas, karena jumlah dan kualifikasinya sudah dapat ditentukan.

Ada beberapa pakar mendefinisikan tentang analisis jabatan (pekerjaan), antara lain;

a. Menurut Pangabean, pengertian analisis pekerjaan adalah sebuah proses penyelidikan yang sistematis untuk memperoleh informasi mengenai jabatan (job) dan pekerjaannya (jobholder $)^{23}$

b. Menurut Siagian, pengertian analisis pekerjaan adalah usaha yang sistematis dalam mengumpulkan, menilai, dan mengorganisasikan semua jenis pekerjaan yang terdapat dalam organisasi. ${ }^{24}$

c. Analisis pekerjaan menurut Veithzal Rivai, adalah suatu proses sistematis

\footnotetext{
${ }^{23}$ Mutiara Panggabean S, Manajemen Sumber Daya Manusia, (Jakarta: Ghalia Indonesia, 2002)

${ }^{24}$ Sondang Siagan, Manajemen Sumber Daya Manusia, (Jakarta: Bumi Aksara, 20017)
}

untuk mengumpulkan informasi atas aspek penting yang berkaitan dengan suatu pekerjaan. ${ }^{25}$

Dari ketiga definisi di atas penulis mencoba untuk menyimpulkan dan menjelaskan makna dari Analisis Jabatan (job), yakni berawal dari arti pekerjaan atau jabatan (job) adalah suatu pola dari tugas-tugas, pekerjaan dan tanggungjawab yang dapat dikerjakan oleh satu orang. Kemudian yang kedua mengetahui informasi pengetahuan tentang jabatanjabatan dan persyaratannya harus dikumpulkan melalui suatu proses yang disebut dengan analisis jabatan, di mana informasi tentang jabatan tersebut secara sistematis dikumpulkan, kemudian yang ketiga di evaluasi dan disusun.

Maka penulis mengartikan analisis jabatan adalah suatu prosedur untuk menentukan tugas-tugas dan keterampilan yang dibutuhkan untuk suatu pekerjaan serta sumber daya insani dengan kualifikasi yang sesuai tugas yang diembankan. Hasil dari analisis jabatan adalah informasi tentang persyaratan jabatan, kemudian dikembangkan menjadi deskripsi jabatan (job description) yang berisikan outline tentang tujuan, tanggungjawab dan tugas-tugas kunci dari jabatan tersebut. Dari sisi lain keterampilan, pendidikan, dan pengalaman yang dibutuhkan untuk mengisi posisi tersebut dinamakan spesifikasi jabatan (job specification). Dan spesifikasi jabatan inilah yang menjadi dasar bagi perbankan syariah untuk menentukan kualifikasi karyawan yang akan diterimanya.

Ada beberapa tujuan dalam analisis pekerjaan, yaitu:

1. Untuk menciptakan SDI yang andal dan menghadapi tantangan teknologi modern.

2. Memberi kenyamanan dalam bekerja di perusahaan.

\footnotetext{
${ }^{25}$ Veithzal Rivai Zainal, Salim Bassalamah, dan Natsir Muhammad, Islamic Human, P.90.
} 
3. Untuk menentukan kualifikasi pekerja secara langsung dalam mencapai keberhasilan perusahaan.

Sedangkan berikut ini kegiatan yang utama pada MSDI dalam mencari informasi analisis jabatan, diantaranya: ${ }^{26}$

1. Mengevaluasi bagaimana tantangan dari lingkungan yang mempengaruhi jabatan individual.

2. Menghilangkan persyaratan jabatan agar tidak terjadi deskriminasi pekerjaan.

3. Menemukan elemen-elemen jabatan yang membentuk atau mengurangi quality of work life.

4. Membuat rencana tentang persyaratan untuk SDI mendatang.

5. Menentukan kebutuhan pelatihan, baik untuk pekerja yang baru maupun yang telah berpengalaman.

6. Merencanakan pengembangan potensi pekerja.

7. Menentukan bentuk standar kinerja yang realitis.

8. Memberi kompensasi yang adil pada pemangku jabatan.

9. Mengetahui kejujuran pemegang jabatan pekerjaan.

Dariinformasi hasil analisis jabatan di atas, penulis menyimpulkan, bahwa informasi yang ada dalam analisis jabatan adalah sangat bermanfaat untuk perencanaan SDI, rekrutmen atau seleksi SDI, penilaian kinerja, pelatihan dan pengembangan, evaluasi jabatan, perencanaan dan pengadaan SDI, merivisi struktur organisasi pekerjaan apabila diperlukan, penganturan kompensasi, imbalan atau reward, serta dapat memberikan data sebagai fungsi pengaturan.

Untuk perbankan baru atau perbankan yang sedang merubah sistem kerjanya, maka sebelum menganalisis jabatan harus diperhatikan pada lima ketentuan, antara lain:

1. Analisis arus-kerja (work-flow analysis), suatu proses menganalisis tugas-tugas untuk menghasilkan barang

\footnotetext{
${ }^{26}$ Ibid., 51
}

atau jasa sebelum dialokasikan kepada karyawan.

2. Analisis jabatan, memiliki tiga tahap pengumpulaninformasi untuk analisis jabatan antara lain:

a. Menemui dan mengenali jabatanjabatan yang akan dianalisis.

b. Mengembangkan daftar pertanyaan untuk analisis jabatan.

c. Mengumpulkan informasi analisis jabatan.

3. Uraian jabatan/ job description (profil dari jabatan), yang merupakan pernyataan tertulis yang menjelaskan tentang apa yang secara aktual dilakukan oleh pemangku jabatan, bagaimana ia mengerjakannya, dan dalam kondisi apa pekerjaan itu dilakukan.

4. Spesifikasi jabatan/ job specification (profil dari karakteristik SDI), dari sini jabatan akan dijelaskan apa yang diminta dari pekerja yang memegang jabatan tersebut dan ketrampilan apa saja yang menjadi syarat.

5. Standar jabatan/ job standard.Dalam KBBI pengertian dari standar adalah ukuran tertentu yang dipakai sebagai patokan. ${ }^{27}$ Yang memiliki dua fungsi, pertama sebagai target upaya yang dicapai pekerja. Kedua sebagai kriteria kemana keberhasilan pekerjaan diukur.

Gambar $1 .^{28}$

Hubungan antara Analisis Jabatan dan Penggunanya.

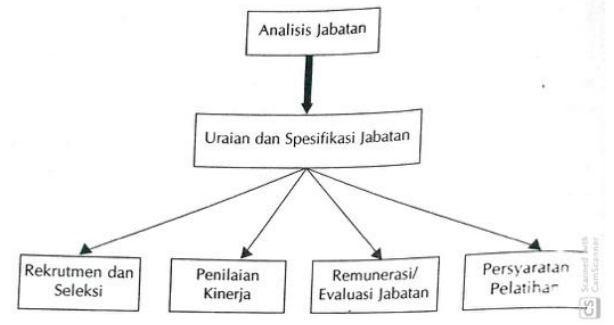

Sumber: Jumalisani 2011

\footnotetext{
${ }^{27}$ http://www.kbbi.kemdikbud.go.id

${ }^{28}$ Jumalisani, Pengelolaan, p. 60.
} 
Dari gambar di atas, menjelaskan pada deskripsi dan spesifik jabatan adalah suatu dokumen tertulis yang berisi tugas dan tanggung jawab pada setiap pekerja, ikhtisar pekerjaan dan kegiatan utama selain yang diperlukan dalam pekerjaan tersebut. Pada gambar tersebut penulis juga ingin menyimpulkan bahwa, apabila suatu perusahaan ingin menyaring atau meneliti karyawan untuk menempatkan jabatannya, maka di butuhkan informasi detail terhadap karyawan tersebut dengan mendeskripsikan atau menguraikan data dirinya dalam pengalaman pekerjaan sebelumnya. Sehingga perusahaan akan menspesifikasikan pada jabatan yang sesuai dengan kemampuannya. Dari dokumentasi tersebut perusahaan dapat menyeleksi (merekrut), menilai kinerjanya, mengevaluasi jabatannya (remunerasi), dan memberikan pelatihan apabila itu sebagai persyaratan pada pekerjaan tersebut. Dalam firman Allah SWT yang telah di tegaskan: ${ }^{29}$

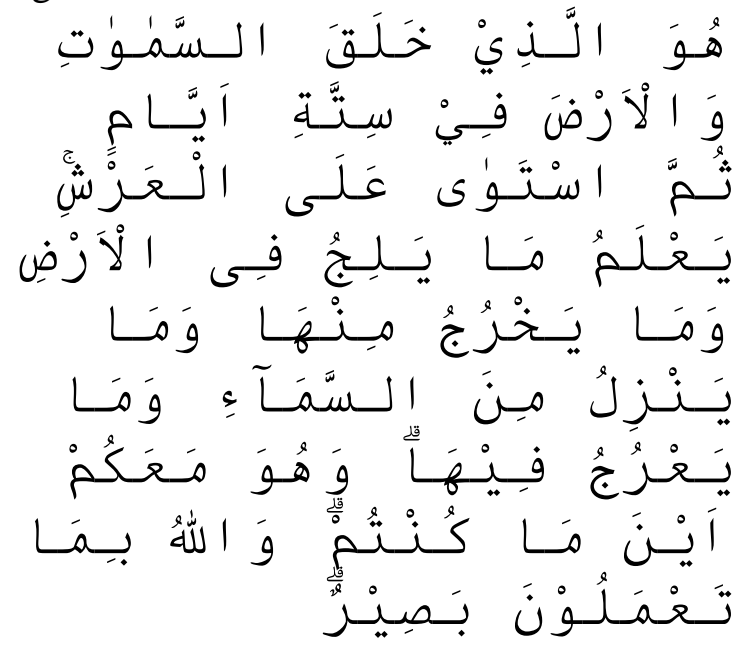

Artinya: Dialah yang menciptakan langit dan bumi dalam enam masa; kemudian Dia bersemayam di atas 'Arsy. Dia mengetahui apa yang masuk ke dalam bumi dan apa yang keluar dari dalamnya, apa yang turun dari langit dan apa yang naik ke sana. Dan Dia bersama kamu di mana saja kamu berada. Dan Allah Maha Melihat apa yang kamu kerjakan.(Q.S AlHadid (57):4)

\footnotetext{
${ }^{29}$ Quran Kemenag, surah Al-Hadid (57), ayat 4.
}

Agar proses menganalisis pekerjaan lebih baik, maka dibutuhkan langkahlangkah analisis jabatan sebagai berikut: Langkah Pertama, menguji organisasi secara keseluruhan dan kecocokan tiap pekerjaan. Langkah Kedua, menentukan informasi analisis pekerjaan akan di gunakan. Langkah Ketiga, memilih jenis pekerjaan untuk diteliti. Langkah Keempat, mengumpulkan data dengan teknik analisis pekerjaan yang dapat diterima. Langkah Kelima, menyiapkan deskripsi tugas. Langkah Keenam, menyiapkan spesifikasi pekerjaan.

Gambar 2. ${ }^{30}$

Langkah-langkah Proses Analisis

Pekerjaan dan Hubungannya dengan SDI serta Rancang Pekerjaan.

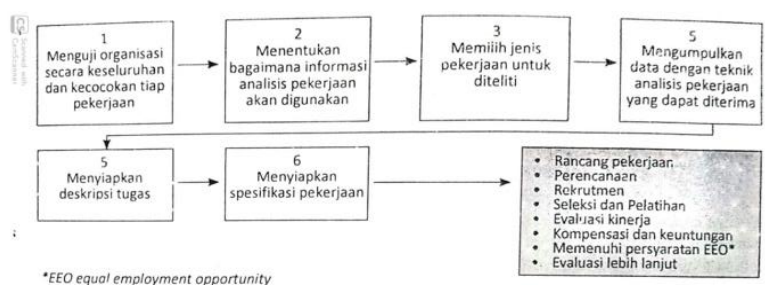

Sumber dari Veithzal Rivai 2014

Dari gambar di atas, penulis ingin menyimpulkan bahwa apabila pada langkah-langkah proses analisis pekerjaan dilakukan dengan benar, maka perusahan dapat malaksanakan perencanaan SDI, merekrut atau menyeleksi SDI, merancang pekerjaan, memberi pelatihan, dan mengevaluasi kinerja.

Sedangkan menurut Andriyanto, langkah-langkah dalam pengelolaan sumber daya insani perbankan syariah sebagai berikut: ${ }^{31}$

\footnotetext{
${ }^{30}$ Veithzal Rivai, Islamic Human, p. 105.

${ }^{31}$ Andrianto dan Anang Firmansyah, Manajemen Bank Syariah Impementasi Teori dan Praktik..., 201-203.
} 
Gambar 3.

Langkah-langkah Pengelolaan SDI

Perbankan Syariah

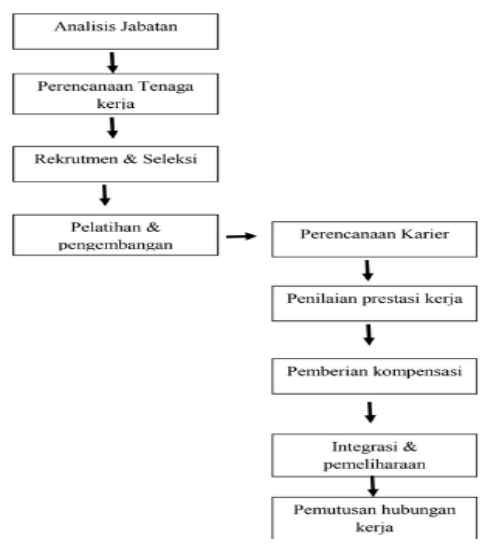

Sumber: Andrianto dan Anang

Firmansyah, 2019

Sedangkan Menurut Casico, ada lima metode yang harus dilakukan analisis jabatan, yaitu: ${ }^{32}$

1) Observasi, merupakan cara untuk mengamati perilaku karyawan secara langsung atau tidak kepada individu atau kelompok.

2) Wawancara, merupakan teknik yang akurat untuk berkomunikasi secara terbuka.

3) Kinerja jabatan (job performance), sebagai pengumpulan informasi untuk memperoleh pandangan dari kedua kelompok kerja dalam perusahaan.

4) Daftar pertanyaan yang terstruktur, teknik ini digunakan untuk menjawab pertanyaan yang berkaitan dengan tugas dan tanggungjawab.

5) Insiden kritis atau bisa disebut juga catatan harian pekerjaan karyawan, teknik ini sebagai informasi yang tepat untuk melihat pekerjaannya setiap hari, setiap tanggal, setiap jam, setiap minggu, atau setiap bulannya. ${ }^{33}$

\footnotetext{
${ }^{32}$ Wayne F Cascio, Managing Human Resource. Productivity, Quality of Work Life, Profit $6^{\text {th }}$. Ed, (McGraw-Hill International Edition, 2003), p. 167.

${ }^{33}$ PAQ (Position Analysis Questionnaires) yang terdiri dari 194 item dan dikatagorikan ke dalam informasi input, proses mental, output pekerjaan, hubungan dengan orang lain, konteks pekerjaan dan karteristik lainnya dari pekerjaan.
}

Setelah mendapatkan informasi pekerjaan yang sesuai dengan langkahlangkah serta metode di atas, maka selanjutnya pada tahap terahir adalah melihat hasil informasi pekerjaan dalam bentuk deskripsi serta menspesifikasikan hasil informasi pekerjaan tersebut yang sesuai dengan syarat yang ditentukan oleh perusahaan, yaitu melaksanakan pekerjaan yang baik, efektif, efisien, dan produktif.

\section{Dasar Perencanaan Sumber Daya Insani di Perbankan Syariah}

Perencanaan

merupakan

pengambilan keputusan sekarang tentang hal-hal yang akan dikerjakan di masa depan. Perencanaan sumber daya insani juga berkaitan pada penentuan kebutuhan akan tenaga kerja di masa depan, baik dalam arti jumlah dan kualifikasinya untuk mengisi berbagai jabatan dan menyelenggarakan berbagai aktivitas yang akan datang. Jumlah dan kualifikasi yang tidak "pas" akan merugikan organisasi. Ketika jumlah berlebihan akan mengakibatkan pemborosan dana dan sekaligus menyulitkan pengawasan. Sedangkan jumlah yang kurang akan memberikan hasil yang tidak baik selain pemborosan juga merugikan perbankan syariah. Demikian pula dengan halnya kualifikasi. Jika kualifikasi tidak sesuai pada penempatan pada suatu pekerjaanya, maka akan berdampak negatif pula pada perusahaan tersebut. Oleh karena itu keputusan yang dituangkan dalam bentuk perencanaan sumber daya insani merupakan satu di antara berbagai putusan strategi dalam organisasi atau perusahaan.

Perencanaan sumber daya insani pada hakekatnya adalah memperkirakan kebutuhan pekerjaan mendatang yang dilihat dari segi kualitas dan kuantitas, kemudian merencanakan orang-orang yang akan mengerjakan berbagai tugas dan pekerjaan dalam organisasi. Sehingga dalam SDM digunakan pertimbangan 
supply and demand seperti pada gambar dibawah ini: ${ }^{34}$

Gambar 4.

Perencanaan Tenaga Kerja

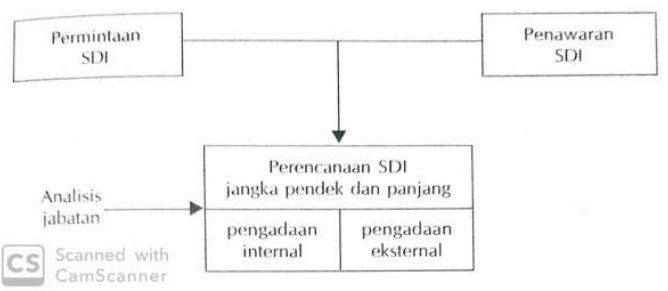

Sumber: Wayne F Cascio 2003

Dari gambar di atas, penulis ingin menjelaskan bahwa suatu perencanaan sumber daya manusia itu dilihat pada pertimbangan permintaan dan penawaran pasar tenaga kerja. Dilihat dari sisi permintaan, perncanaan SDI merupakan proses penentuan jabatan, sedangkan dari sisi penawaran sebagai peluang di pasar tenaga kerja. Maka perencanaan SDI harus mengenali kebutuhan-kebutuhan tenaga kerja di perusahaan atau organisasi untuk jangka pendek atau jangka panjang.

Adapun tujuan perencanaan SDI adalah sebagai berikut: ${ }^{35}$

1. Untuk menetukan kualitas dan kuantitas karyawan yang akan mengisi semua jabatan dalam perusahaan.

2. Untuk menjamin tersedianya tenaga kerja masa kini atau masa depan sehingga setiap pekerjaan ada yang mengerjakan.

3. Supaya tidak terjadi mismanajemen dan tumpang tindih dalam pelaksanaan tugas.

4. Untuk mempermudah koordinasi, integrasi, dan sinkronisasi (KIS) sehingga produktivitas kerja meningkat.

5. Untuk menghindari kekurangan dan atau kelebihan karyawan.

6. Untuk menjadi pedoman dalam menetapkan program penarikan, seleksi, pengembangan, kompensasi, pengintergrasian, pemeliharaan, kedisiplinan, dan pemberhentian karyawan.

\footnotetext{
${ }^{34}$ Ibid., 63

${ }^{35}$ Ibid., 50
}

7. Menjadi pedoman dalam melaksanakan mutasi (vertikal atau horizontal) dan pensiun karyawan.

8. Menjadi dasar dalam melakukan penilaian karyawan.

Perusahan yang sehat adalah perusahaan yang memiliki suatu perencanaan manajemen sumber daya insani yang matang, karena setiap perusahaan pasti menghadapi masa depan yang selalu di selimuti oleh ketidakpastian dan sumber daya yang terbatas. Oleh karena itu perencanaan SDI memiliki delapan manfaat, di antaranya: ${ }^{36}$

1. Perusahaan dapat memanfaatkan SDI yang ada dalam perusahaan secara lebih baik.

2. Evektivitas kerja dapat ditingkatkan apabila SDI yang ada telah sesuai dengan kebutuhan perusahaan.

3. Produktivitas dapat lebih baik ditingkatkan, apabila memiliki data tentang pengetahuan, pekerjaan, pelatihan yang telah diikuti oleh SDI

4. Dapat menentukan kebutuhan tenaga kerja di masa kini dan di masa depan.

5. Dapat menangani informasi ketenaga kerjaan yang mencakup banyak hal pada perusahaan.

6. Dapat memahami situasi pasar tenaga kerja.

7. Dapat menyusun program kerja yang realistik.

8. Sebagai acuan dalam menyusun program pengembangan SDI.

Adapun faktor-faktor yang mempengaruhi perencanaan SDI adalah sebagai berikut: ${ }^{37}$

a. Perubahan Demografi, Kecakapan pada SDI sangatlah diperlukan pada perusahaan, karena setiap SDI yang lahir pada era mendatang, sangat penting untuk dijadikan informasi kependudukan yang akan di analisis.Ada empat faktor

\footnotetext{
${ }^{36}$ Veithzal Rivai Zainal, Salim Bassalamah, dan Natsir Muhammad, Islamic Human Capital Management Manajemen Sumber Daya Insani, p. 44-48.

${ }^{37}$ Ibid, p. $39-40$.
} 
demografi yang mempengaruhi perencanaan ssumber daya insani, yaitu:

1) Jumlah penduduk

2) Perluasan tenaga kerja

3) Tenaga kerja perempuan

4) Tingkat pengetahuan yang dimiliki tenaga kerja.

b. Perubahan Ekonomi, kondisi ekonomi dapat mempengaruhi manajemen Sumber Daya Insani, seperti inflasi yang dapat merusak perencanaan biaya hidup seseorang.

c. Perubahan Teknologi, pengembangan dan penerapan teknologi baru memiliki pengaruh yang besar terhadap praktik organisasi dan manajemen, seperti pengembangan teknologi canggih di bidang produksi.

d. Kondisi Peraturan dan PerundangUndangan, hukum sangat berpengaruh pada manajemen perencanaan SDI, karena adanya Undang-Undang yang harus melindungi karyawan pada kesehatan dan keselamatan kerja.

e. Perubahan Prilaku Terhadap Karier dan pekerjaan, ada tiga yang mengakibatkan perubahan prilaku terhadap karier dan pekerjaan, diantaranya; pertama meningkatnya partisipasi perempuan dalam dunia kerja, kedua pola atau bentuk baru pergeseran karyawan, dan ketiga perubahan sikap terhadap karier dan nilai individual terhadap karier.

Beberapa hal penting yang perlu diperhatiakan dalam pelaksanaan perencanaan SDI, yaitu: ${ }^{38}$

1. Isu SDI adalah hal yang sangat penting dan mendasar dalam perusahaan secara luas.

2. Perencanaan SDI sebagai proses untuk menggapai berbagai isu tersebut, dan membuat kebijakan baru, sistem dan program yang menjamin pengelolaan SDI di bawah kondisi yang tidak pasti (cepat berubah).

3. Peran staf profesional mengalami perubahan dalam perencanaan SDI, proses tersebut tetap dalam alur

\footnotetext{
${ }^{38}$ Ibid, p. 54.
}

aktivitas manajemen, yang berhubungan dengan perencanaan bisnis yang sedang berjalan.

4. Peramalan kebutuhan SDI merupakan faktor yang sangat penting dalam rangka mengantisipasi perubahan staf dan keperluan perusahaan.

5. Manajemen kinerja melibatkan perencanaan dan pelaksanaan program untuk memperbaiki produktivitas melalui aktivitas kerja, penilaian dan pengembangan kemampuan karyawan, perencanaan dan penilaian kerja, dan pelaksanaan kompensasi.

6. Manajemen karier menyediakan suatu proses koordinasi untuk pengangkatan, seleksi dan penempatan, promosi dan pertukaran, latihan dan pengembangan, dan kegiatan lainnya yang mempengaruhi perencanaan dan pengembagan karier seseorang. Dan perhatian penting diberikan pada pengembangan karier manajer yang memiliki bakat dan kemampuan tinggi.

\section{PENUTUP}

Dari penjelasan di atas, maka penulis menyimpulkan bahwa:

1. Definisi Manajemen Sumber Daya Manusia (MSDM) dengan Manajemen Sumber Daya Insani (MSDI) tidaklah jauh berbeda, namun hanya berbeda dalam kata manusia pada umumnya dengan kata insani yang dengan kata insani yang bermakna insan kamil (dalam bahasa Arab) atau manusia seutuhnya ( $a$ whole man concept). Manajemen yang sama-sama memiliki arti pengelolaan pada perusahaan untuk memaksimalkan efektifitas organisasi yang terdiri dari banyak aktivitas terkait satu dengan yang lainnya (interdependen) dalam mencapai tujuannya. Sedangkan dalam manajemen Sumber Daya Insani pada Perbankan Syariahmemiliki empat fungsi dasar diataranya: perencanaan (planning/ at-takhthiith), Pengorganisasian (organizing/ attanziem), Pengarahan (actuating/ at- 
tansiiq) dan Pengadaan, Pengendalian (controlling/ al-muraqabah).

2. Terdapat enam langkah dalam menganalisis pekerjaan yang lebih baik, yaitu: Menguji organisasi secara keseluruhan dan kecocokan tiap pekerjaan, menentukan informasi analisis pekerjaan akan di gunakan, memilih jenis pekerjaan untuk diteliti,mengumpulkan data dengan teknik analisis pekerjaan yang dapat diterima, menyiapkan deskripsi tugas, Dan menyiapkan spesifikasi pekerjaan.

3. Dalam perencanaan sumber daya insani, memiliki hal-hal yang perlu diperhatikan, diantaranya: isu SDI, perencanaan SDI, peran staff profesional, peramalan kebutuhan SDI, manajemen kinerja, dan manajemen karier.

\section{DAFTAR PUSTAKA}

Al Hasan, Fahadil Amin dan Muhammad Irfan Maulana, "Meningkatkan Kualitas Sumber Daya Insani di Lembaga Keuangan Syariah dalam Menghadapi Persaingan Global", Sosio Didaktika, Vol.3, No.1, (Juni, 2016).

Anang Firmansyah, dan Andrianto, Manajemen Bank Syariah Impementasi Teori dan Praktik (T.tt: Qiara Media, 2019)

Arifin, Zainul. Dasar-Dasar Bank Syariah (Jakarta: Azkia Publisher, 2009).

Hasibuan, Melayu S.P, Manajemen Sumber Daya Manusia, Jakarta: Bumi Aksara, 2003.

Juhdi, Fathullah, Manajemen Sumber Daya Manusia, Malang: Cita Intrans Selaras, 2018.

Jusmaliani, Pengelolaan Sumber Daya Insani, Jakarta: Bumi Aksara, 2011.

Makhrus, "Peran Perguruan Tinggi dalam Mendorong Pengembangan Sumber Daya Insani pada Lembaga Keuangan Syariah”, Islamadina, Vol .XV, No.2, (November : 2015)

Mamik, Manajemen Sumber Daya Manusia (Sidoarjo: Zifatama Jawara, 2016).

Panggabean S, Mutiara, Manajemen Sumber Daya Manusia, Jakarta: Ghalia Indonesia, 2002.

Priyono dan Marnis, Manajemen Sumber Daya Manusia, Sidoarjo: ZIFATAMA Publiser, 2008.

Saihudin, Manajemen Sumber Daya Manusia (Ponorogo: Uwais Inspirasi Indonesi, 2019).

Siagan, Sondang, Manajemen Sumber Daya Manusia, Jakarta: Bumi Aksara, 20017.

Silviana Pebruary, dkk, Pencegahan Fraud di Lembaga Keuangan Mikro Syariah (Yogyakarta: Deepublish, 2020).

Wayne F Cascio, Managing Human Resource. Productivity, Quality of Work Life, Profit $6^{\text {th }}$. Ed, McGraw-Hill International Edition, 2003.

Zainal, Veithzal Rivai., Bassalamah, Salim., dan Muhammad, Natsir., Islamic Human Capital Management Manajemen Sumber Daya Insani, Jakarta: PT RajaGrafindo Persada, 2014.

المعجم الاوسط باب الألف, من اسمه أحمد, الخز 1 الصفحة 275

http://www.qurankemenag.go.id

http://www.kbbi.kemdikbud.go.id 
